\title{
Human health risk assessment of uranium in drinking water sampled from drilled wells located in rural areas of the Lower Silesian region (Poland)
}

\author{
Sławomir Garboś*, Dorota Święcicka \\ National Institute of Public Health - National Institute of Hygiene, Poland \\ Department of Environmental Hygiene \\ *Corresponding author's e-mail: sgarbos@pzh.gov.pl
}

Keywords: uranium, well water, rural areas, human exposure, health risk assessment, ICP-MS.

\begin{abstract}
Uranium concentrations in groundwater taken from private drilled wells have been never determined in Poland, implying a lack of available data to quantify the human exposure to $U$ through drinking water consumption, especially in rural areas influenced by mining activities. The main aim of the study was the assessment of human health risk related to the consumption of well waters containing $\mathrm{U}$, collected from selected rural areas of the Lower Silesian region (Poland). The random daytime (RDT) sampling method was applied to the collection of well waters from three control study areas (CSA): Mniszków (CSA-A), Stara Kamienica/M. Kamienica/Kopaniec (CSA-B) and Kletno (CSA-C). The analyses of RDT samples were performed by validated method based on inductively coupled plasma mass spectrometry (ICP-MS). Uranium concentration ranges in well waters and the estimated geometric means for individual control study areas were: $0.005-1.03 \mu \mathrm{g} / \mathrm{L}$ and $0.052 \mu \mathrm{g} / \mathrm{L}$ (CSA-A), $0.027-10.6 \mu \mathrm{g} / \mathrm{L}$ and $0.40 \mu \mathrm{g} / \mathrm{L}$ (CSA-B), and $0.006-27.1 \mu \mathrm{g} / \mathrm{L}$ and $0.38 \mu \mathrm{g} / \mathrm{L}$ (CSA-C). The average and individual chronic daily intakes (CDI) of $\mathrm{U}$ by drinking water pathway (adults/children) were in the ranges of: $0.0017-0.013 / 0.0052-0.040 \mu \mathrm{g} \cdot \mathrm{kg}^{-1} \cdot \mathrm{day}^{-1}$ and $0.0002-0.90 / 0.0005-2.71 \mu \mathrm{g} \cdot \mathrm{kg}^{-1} \cdot \mathrm{day}^{-1}$. The average \%TDI and ranges of individual \%TDI (adults/children) were: $0.17 \% / 0.52 \%$ and $0.02-3.4 \% / 0.05-10.3 \%$ (CSA-A), $1.3 \% / 4.0 \%$ and $0.09-35 \% / 0.27-106 \%$ (CSA-B), and $1.3 \% / 3.8 \%$ and $0.02-90 \% / 0.06-271 \%$ (CSA-C). The estimated average CDI values of $\mathrm{U}$ through well water are significantly lower than the TDI $\left(1 \mu \mathrm{g} \cdot \mathrm{kg}^{-1} \cdot \mathrm{day}^{-1}\right)$, while for individual CDI values the contribution to the TDI can reach even $90 \%$ (adults) and $271 \%$ (children), indicating essential human health risk for children consuming well water from private drilled wells located in CSA-B and CSA-C (5.3\% of total number of samples collected).
\end{abstract}

\section{Introduction}

Uranium is a naturally occurring lithophilic heavy metal in the environment characterized by radioactivity and chemical toxicity. This metal is widespread in nature, occurring in several minerals mainly as U(IV) and U(VI) (Harper and Kantar 2008). The principal uranium minerals include uraninite, pitchblende, coffinite, brannerite and thucholite, while secondary uranium minerals are: autunite, carnotite, gummite, seleeite, torbernite, tyuyamunite, uranocircite, uranophane and zeunerite (Závodská et al.2013). This metal is present in surface water and groundwater as a result of emissions from natural and anthropogenic sources - mineral deposits, mill tailings, the nuclear industry, the combustion of coal and other fuels, the application of phosphate fertilizers containing uranium (Závodská et al. 2013) and dumping sites (Suponik and Lutyński 2009). Under oxidizing conditions, uranium can migrate relatively long distances from its source, and in water it is most commonly found in the hexavalent form (the uranyl ion (Harper and Kantar 2008)).

In adults, up to $5 \%$ of ingested uranium is adsorbed in the gastrointestinal tract while the remaining approx. $95 \%$ is eliminated via feces and in smaller degree is excreted in urine (Wrenn et al 1985, Zamora et al. 2002). Following ingestion, this metal appears in the bloodstream and it subsequently accumulates in the skeleton, the kidneys, and in smaller degree in the liver. Its negative radiological health effect is based on alpha and gamma emissions which may lead to DNA damage and contribute to carcinogenesis (Sheppard 1980). However, considerations based only on the radiological effects of this metal are not sufficient to protect human health, since they do not provide any information on chemical toxicity of uranium. Such toxic effects connected with the exposure to uranium include nephritis (kidney disease) (Kurttio et al. 2002) and changes to bone structure (Kurttio et al. 2005). Human studies have shown elevated alkaline phosphatase levels and increased excretion of urinary $\beta$-microglobulin (Zamora et al. 1998) in people with elevated uranium exposure via drinking water.

Concentrations of $U$ in most groundwaters are usually low, typically in the range $0.1-1 \mu \mathrm{g} / 1$ (Smedley et al. 2006), but they can reach a few thousands $\mu \mathrm{g} / \mathrm{L}$ as a result of reactions with mineral deposits in aquifers. In the cases of private drilled wells that tap groundwater, uranium concentrations were 
determined in the ranges of: $<0.02-48.0 \mu \mathrm{g} / \mathrm{L}$ (Smedley et al. 2006) (England \& Wales), 0.015-8.95 $\mu \mathrm{g} / \mathrm{L}$ (Schnug et al. 2005) (Germany), 0.061-10.02 $\mu \mathrm{g} / \mathrm{L}$ (Katsoyiannis et al. 2007) (Greece) and 0.001-1920 $\mu \mathrm{g} / \mathrm{L}$ (Kurttio et al. 2002) (Finland).

The maximum admissible concentration (MAC) of uranium in drinking water is set by US EPA at the level of $30 \mu \mathrm{g} / \mathrm{L}$ (US EPA 2009). The Annex I (Part B) of Council Directive 98/83/EC (European Community 1998) lists parametric values for various chemical parameters (including metals) existing in drinking water, nevertheless, in the case of $U$ no parametric value has been established. However, some member states have set MAC for $U$ in drinking water at the levels of: $10 \mu \mathrm{g} / \mathrm{L}$ (Germany (Bundesministerium für Gesundheit 2001)), $60 \mu \mathrm{g} / \mathrm{L}$ (Bulgaria (European Food Safety Authority 2009)), $100 \mu \mathrm{g} / \mathrm{L}$ (Finland (European Food Safety Authority 2009)) and $6.8 \mu \mathrm{g} / \mathrm{L}$ (Slovenia (European Food Safety Authority 2009)), while the World Health Organization (WHO) has proposed the provisional guideline value of $30 \mu \mathrm{g} / \mathrm{L}$ in 2011 (World Health Organization 2011).

In Poland, there are large numbers of private drilled wells in operation and they are used on a permanent basis. Uranium concentration levels in groundwater taken from private drilled wells located in uranium-rich bedrock have never been determined in Poland, implying a lack of available data to quantify the human exposure to this metal through drinking water consumption in rural areas, especially influenced by mining activities. The Lower Silesian region situated in south-western Poland has a heterogeneous geological composition with a considerable variability with regard to uranium content in rocks, soil, surface and groundwater.

In terms of costs, practicality and consumer acceptance, random daytime (RDT) sampling method is the most favorable protocol for water quality compliance monitoring (Cardew 2003). The RDT method is based on taking $1 \mathrm{~L}$ of drinking water directly from the tap used for consumption water drawing (usually the kitchen tap) at a time randomly chosen within the working day, during normal office hours (no water abstraction, flushing, cleaning of the tap are applied prior to the sampling). This sampling method has been used for monitoring metals concentrations in drinking water in the UK since 1989 (Hayes and Croft 2012) and in the Netherlands since 2004 (Slaats et al. 2007).

The aim of the study was the determination of uranium in groundwater samples collected from private drilled wells located in selected rural areas of the Lower Silesian region (Poland). Based on the determined uranium concentrations, the human health risk (both average and individual - chronic daily intake values and their percentage values of the tolerable daily intake value proposed by WHO in 2011 (World Health Organization 2011) connected with the consumption of well waters in three rural areas (Mniszków, Stara Kamienica/Mała Kamienica/Kopaniec and Kletno) was assessed.

\section{Material and methods}

\section{Chemical analysis}

\section{Instrumentation}

Inductively coupled plasma mass spectrometer with collision cell - XSeries II CCT (Thermo Electron Corporation, UK) was applied for the determination of uranium in drinking water (target isotope monitored $-{ }^{238} \mathrm{U}$ ). The ICP-MS spectrometer was equipped with a sample introduction system which consisted of: three channel peristaltic pump, glass concentric nebulizer, "impact bead" type conical spray chamber (cooled to $2{ }^{\circ} \mathrm{C}$ with use of Peltier system), one-piece quartz torch (1.5 mm sample injector) with silver-screen shield, and nickel sampling and skimmer cones.

\section{Reagents and solutions}

All tune and calibration solutions were prepared in calibrated PMP volumetric flasks class A (Brand, Germany) with use of deionized water obtained in Simplicity 185 UV water purification system (Millipore SAS, France) and UltraPUR concentrated nitric acid $(60 \% ; \rho=1.37 \mathrm{~g} / \mathrm{mL}$; GR; Merck, Germany). Calibrated micropipettes Finnpipette with adequate disposable micropipette tips Finntip (Thermo Electron Corporation, USA) were used for dosage of stock solutions and concentrated nitric acid. The tune solution of $\mathrm{Ba}, \mathrm{Be}, \mathrm{Bi}, \mathrm{Ce}$, $\mathrm{Co}, \mathrm{In}, \mathrm{Li}, \mathrm{Ni}, \mathrm{Pb}$ and $\mathrm{U}$ at the concentration levels of $1 \mu \mathrm{g} / \mathrm{L}$ was prepared by dilution of stock solution "Analityk-CAL-40" (Inorganic Ventures, USA) and applied for preliminary optimization of ICP-MS spectrometer performance.

Five calibration solutions containing $U$ in the concentration range of $0.5-4 \mu \mathrm{g} / \mathrm{L}$ and yttrium at the concentration level of $10 \mu \mathrm{g} / \mathrm{L}$ (internal standard) were prepared by appropriate dilutions of stock solutions (reference materials): "IMS-102" (Ultra Scientific, USA) containing $U$ at the concentration level of $10 \mu \mathrm{g} / \mathrm{mL}$ and "Yttrium ICP Standard $1000 \mathrm{mg} / \mathrm{L}$ Y CertiPUR" (Merck, Germany).

Trueness of the determinations of $\mathrm{U}$ was monitored using certified reference material (CRM): TM-27.3 "A trace element fortified calibration standard" (Environment Canada, Canada) with U concentration $-2.03 \mu \mathrm{g} / \mathrm{L}$.

"Check standard" solution containing U at the concentration level of $0.997 \mu \mathrm{g} / \mathrm{L}$ and $\mathrm{Y}$ at the concentration level of $10 \mu \mathrm{g} / \mathrm{L}$ was prepared by appropriate dilutions of stock solution "VAR-CAL-2" (Inorganic Ventures, USA) and the above-mentioned yttrium stock solution.

\section{Validation parameters and quality control (QC) scheme}

Several validation parameters were established in order to characterize the analytical method of $U$ determination in water by ICP-MS, including: limit of detection (LOD): $0.42 \mathrm{ng} / \mathrm{L}$ $\left(3 \cdot \sigma_{\text {blank }}\right.$ criterion), limit of quantification (LOQ): $1.3 \mathrm{ng} / \mathrm{L}$ $\left(9 \cdot \sigma_{\text {blank }}\right.$ criterion), working linear range: LOQ $-4 \mu \mathrm{g} / \mathrm{L}$, precision as repeatability: $0.68 \%, 0.67 \%$ and $1.5 \%$ (estimated at $\mathrm{U}$ concentrations of $0.05 \mu \mathrm{g} / \mathrm{L}, 0.2 \mu \mathrm{g} / \mathrm{L}$ and $1.0 \mu \mathrm{g} / \mathrm{L}$, respectively, in the presence of test water matrix), average recovery in the presence of test water matrix: $97 \% \pm 1.1 \%$, trueness : $-3.1 \%$, and expanded uncertainty: $8 \%(\mathrm{k}=2 ; \mathrm{P}=95 \%)$.

Validation parameters of the developed method of $\mathrm{U}$ determination in water - LOD, precision and trueness meet the requirements usually related to other metal determinations in drinking water listed in the Directive 98/83/EC (European Community 1998): LOD (10\% of WHO MAC $=30 \mu \mathrm{g} / \mathrm{L})$ $\leq 3 \mu \mathrm{g} / \mathrm{L}$; precision $\leq 10 \%$; trueness within the range of $\pm 10 \%$.

The analytical quality control scheme described previously for other elements (Garboś and Święcicka 2012a) was applied for the determination of $U$ in water using ICP-MS. It consists of maintenance of optimal performance of ICP-MS spectrometer using the tune solution, calibration of ICP-MS 
spectrometer, performing fixed sequence of analytical batch (run) for obligatory measurements.

Calibration of ICP-MS spectrometer was performed at the beginning of each measurement day. Correlation coefficients better than 0.9999 were achieved in all cases of ICP-MS calibrations applied for the determination of $U$.

Each sequence of analytical batch consisted of 15 sample measurements (or less for shorter series of analytical samples) with obligatory measurements of: procedural (reagent) blank, analytical samples (samples No. 1-10), replicate sample (this sample is obtained by dividing one of analytical samples No. 1-10 into two sub-samples), "on-field" blank, "check standard", and CRM.

Appropriate control charts were prepared for blank level monitoring. No statistically essential change of the LOD for uranium previously established during validation process was observed (in both cases of data analysis based on procedural blanks and "on-field" blanks). Trueness of determination of U was monitored during each measurement day using CRM and additionally "check standard" measurements were performed for control the stability of calibration. All results of $\mathrm{U}$ determinations in CRM were achieved with trueness better than $\pm 5 \%$. All estimated precisions of $U$ determinations in replicate sample and in correlated original analytical sample expressed as RSDs were better than $5 \%$ (for average $U$ concentrations $\geq 0.1 \mu \mathrm{g} / \mathrm{L}$ ).

\section{The control study areas and groundwater sampling procedure}

The current investigation is focused on three rural areas located in the Lower Silesian region (Poland), where drinking water used for consumption purposes is taken from the private drilled wells based on groundwater intakes. The following three control study areas (CSA) were investigated: Mniszków (CSA-A) - Fig. 1, Stara Kamienica/Mała Kamienica/Kopaniec (CSA-B) - Fig. 2, and Kletno (CSA-A) - Fig. 3.

Uranium mining activities in the above-mentioned areas were extensive between 1950-1951 (CSA-A), 1948-1953 (CSA-B), and 1951-1962 (CSA-C) (Hartsch et al. 2007), with relatively low production of uranium ores. The mines (based on underground mining) located in these areas, delivered uranium for Soviet nuclear programs started after the Second World War. The contents of this metal in the extracted ores were: $0.2 \%$ (CSA-A), from $0.08 \%$ to $0.3 \%$ (CSA-B) and from $0.26 \%$ to $0.99 \%$ (CSA-C), while the total amounts of produced $\mathrm{U}$ were: $4.531 \mathrm{t}$ (CSA-A), $6.32 \mathrm{t}$ (CSA-B) and $20.713 \mathrm{t}$ (CSA-C) (Hartsch et al. 2007). Due to extensive mining activities performed, several devastated objects of mine infrastructure are situated in these areas (ruins, drifts, mineshafts, handling places of ores, devices for enrichment of ore, etc.). Additionally, mine slag heaps are typical remains from extensive processing uranium containing ore deposits that are present within short distance to private houses $\left(69800 \mathrm{~m}^{3}\right.$ - CSA-A, $8500 \mathrm{~m}^{3}$ - CSA-B) (Hartsch et al. 2007).

38 groundwater samples (15 - CSA-A, 13 - CSA-B and $10-\mathrm{CSA}-\mathrm{C}$ ) were collected by RDT sampling method in April-May 2012. The description of applied RDT method of the study has been reported previously in detail (Witczak et al. 2011). Well water samples (1 L) were collected into HDPE containers directly from the consumer's taps, according to PN-EN ISO 5667-3:2005. The RDT samples were collected in standalone houses mostly equipped with the domestic

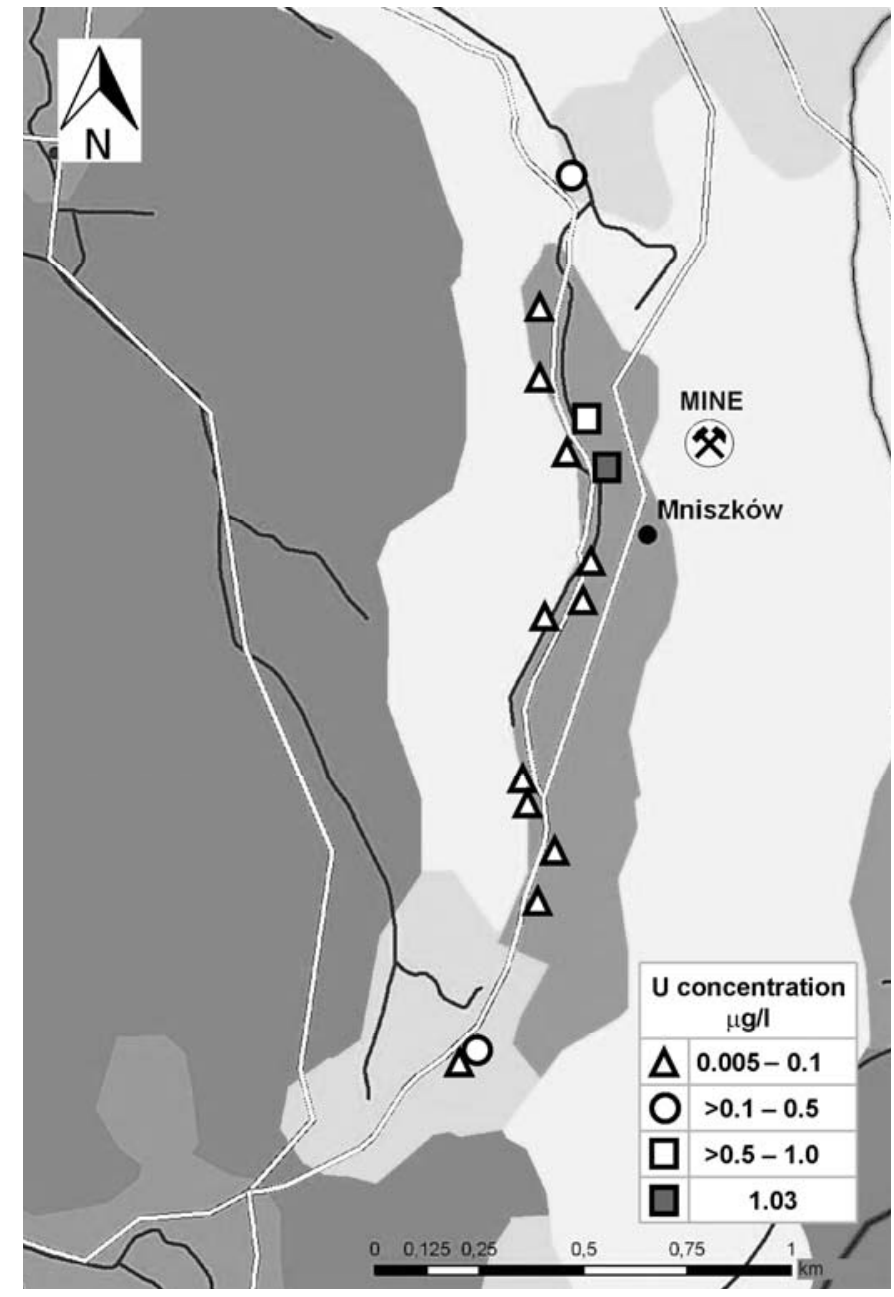

Fig. 1. Distribution of uranium concentrations in well water samples collected from private drilled wells located in Mniszków (CSA-A)

distribution systems directly connected to private drilled wells. In a few cases, when such systems were not connected to groundwater wells, samples were collected directly from the drilled wells. The samples were filtered on-site with use of syringe PTFE filters (pore size $=0.45 \mu \mathrm{m}$; Millipore, USA), and acidified by concentrated nitric acid $(0.5 \mathrm{~mL}$ per $100 \mathrm{~mL}$ of a sample). After collection, the samples were transported and stored in refrigerator at $4^{\circ} \mathrm{C} \pm 2.5^{\circ} \mathrm{C}$ before analysis.

\section{Human health risk assessment}

Uranium enters the human body through several pathways, including the food chain, dermal contact and inhalation, but in comparison with oral intake, all other entry routes are usually negligible. The average and individual chronic daily intake (AVG CDI and IND CDI) values of uranium connected with the consumption of drinking water in the control study areas were calculated according to the previously described equations (Garboś and Święcicka 2012b):

$$
\begin{aligned}
& A V G C D I=\left(\mu_{g} \times I R_{W}\right) / B W \\
& I N D C D I=\left(c_{U} \times I R_{W}\right) / B W
\end{aligned}
$$

where, $\mu_{\mathrm{g}}, \mathrm{c}_{\mathrm{U}}, \mathrm{IR}_{\mathrm{W}}$ and $\mathrm{BW}$ represent the estimated geometric mean of uranium concentration in drinking water $(\mu \mathrm{g} / \mathrm{L})$, the determined uranium concentration in drinking water sampled 


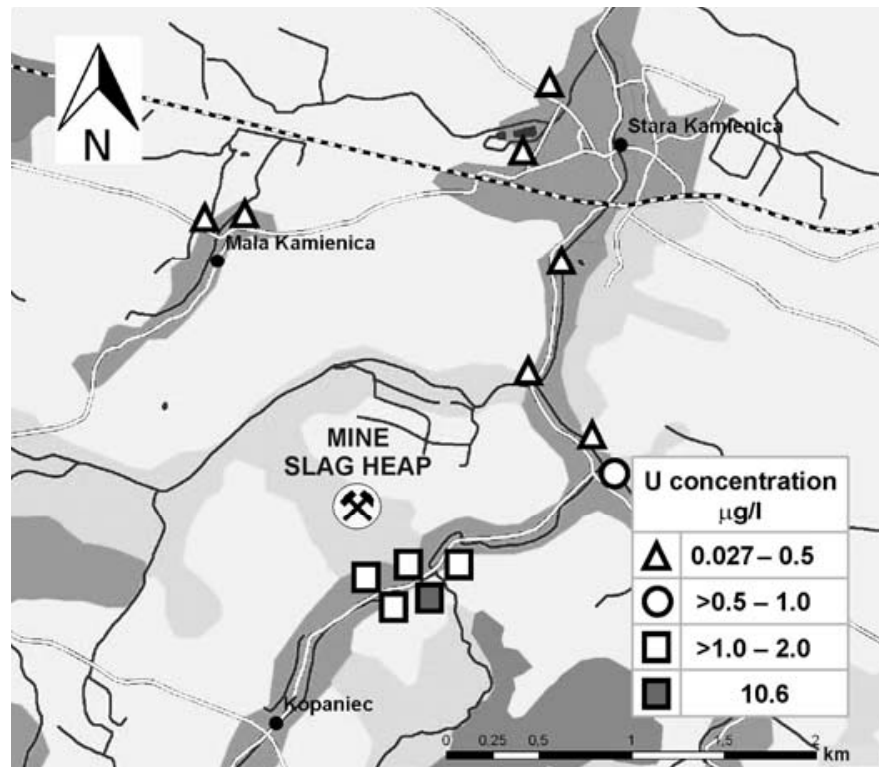

Fig. 2. Distribution of uranium concentrations in well water samples collected from private drilled wells located in Stara Kamienica/M. Kamienica/Kopaniec (CSA-B)

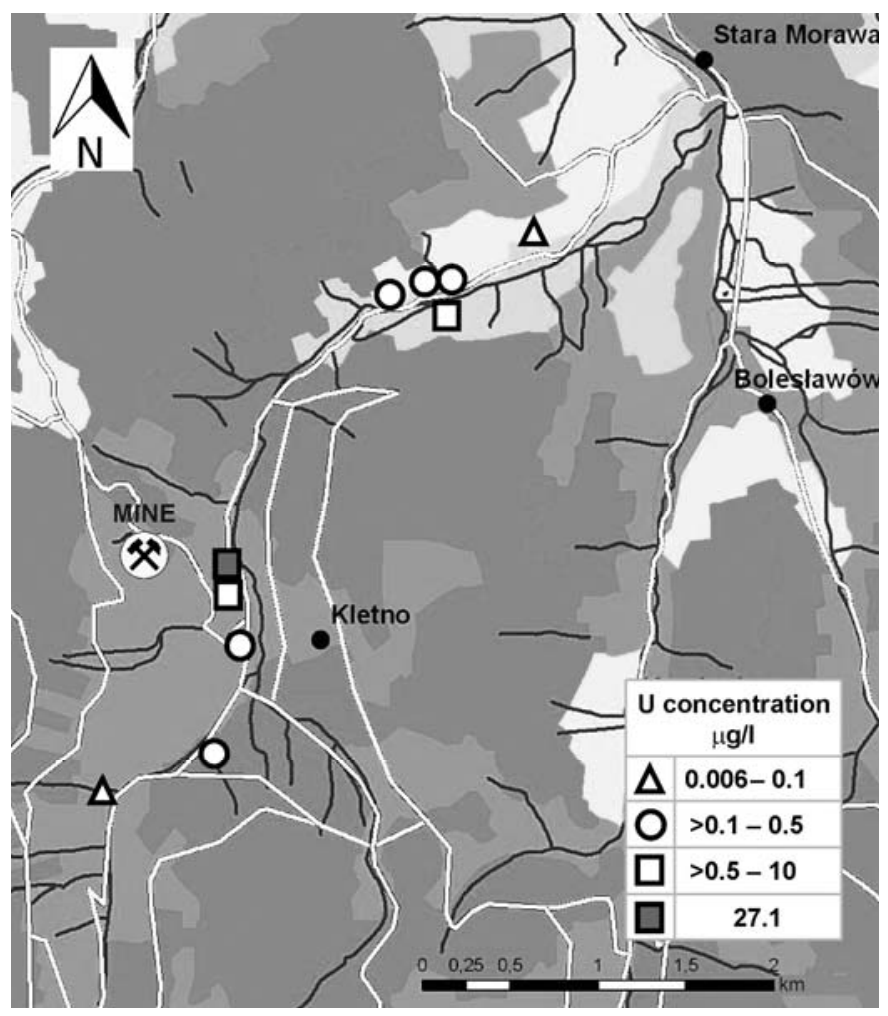

Fig. 3. Distribution of uranium concentrations in well water samples collected from private drilled wells located in Kletno (CSA-C)

from the individual sampling point located in the CSA, the ingestion rate of drinking water $(2 \mathrm{~L} /$ day - adults or $1 \mathrm{~L} /$ day - children) and body weight (60 kg - adults or $10 \mathrm{~kg}$ - children), respectively.

The average and individual percentage values of tolerable daily intake (AVG \% TDI and IND \% TDI) of uranium are estimated by comparing the calculated AVG CDI and IND CDI with the TDI value for this metal $\left(1 \mu \mathrm{g} \mathrm{kg}^{-1} \cdot \mathrm{day}^{-1}\right.$ (World
Health Organization 2011)) - according to the following equations:

$$
\begin{gathered}
A V G \% T D I=(A V G C D I / T D I) \times 100 \% \\
I N D \% T D I=(I N D C D I / T D I) \times 100 \%
\end{gathered}
$$

\section{Statistical evaluation}

Statistica software v. 7.1 (StatSoft Inc., USA) was applied to statistical testing (Kolmogorov-Smirnov with Lilliefors correction and Shapiro-Wilk normality tests) of the log-normal probability plots constructed for the data sets of results of $U$ determinations in RDT samples. Additionally, the correlation coefficients ( $r$ ) were estimated using the e-stat statistical package (http://www.chem.uw.edu.pl/stat/e-stat/index.htm).

\section{Results and discussion}

The distributions of uranium concentrations in well water samples collected from private drilled wells located in Mniszków (CSA-A), Stara Kamienica/M. Kamienica/Kopaniec (CSA-B) and Kletno (CSA-C) were presented in Fig. 1, Fig. 2 and Fig. 3, respectively. The determined $U$ concentrations in well water samples were in the ranges of $0.005-1.03 \mu \mathrm{g} / \mathrm{L}$ (CSA-A), 0.027-10.6 $\mu \mathrm{g} / \mathrm{L}$ (CSA-B), and 0.006-27.1 $\mu \mathrm{g} / \mathrm{L}$ $(\mathrm{CSA}-\mathrm{C})$. High variability of uranium concentrations in the well waters sampled from different private drilled wells was found. This phenomenon can be related to the fact that this metal in the ground tends to form very well demarcated, concentrated pockets of ore. In general, the highest concentrations of $U$ were found in the cases of private groundwater wells situated within the shortest distance from the former uranium mines and/or mine slag heaps.

The statistical testing of the correlation coefficients of the log-normal probability plots constructed for the data sets of results of uranium determinations in RDT samples (collected from CSA-A, CSA-B and CSA-C) indicated at the significance level of $\alpha=0.05$ that they follow log-normal distributions (correlation coefficients $\geq 0.971$ ). For the log-normal distributions of the $U$ results a statistical analyses were employed and the obtained characteristic parameters (medians, $90^{\text {th }}$-percentiles, $\mathrm{U}$ concentration ranges, $t$-Student parameters and confidence intervals) are included in Table 1.

The total numbers of RDT samples collected from CSA-A, CSA-B and CSA-C were as follows: 15, 13 and 10 (Table 1). The geometric means of $U$ concentration for CSA-B $(0.40 \mu \mathrm{g} / \mathrm{L})$ and CSA-C $(0.38 \mu \mathrm{g} / \mathrm{L})$ were considerably higher than that calculated for CSA-A $(0.052 \mu \mathrm{g} / \mathrm{L})$. Therefore the population living in the area CSA-A can be classified as the low-exposure group (the maximum observed $\mathrm{U}$ concentration $=1.03 \mu \mathrm{g} / \mathrm{L})$.

On the basis of the above-mentioned data, the human health risk connected with the consumption of well water containing uranium was assessed. Table 2 summarizes the estimated average and ranges of individual chronic daily intake (CDI) values (adults and children) and average and ranges of individual percentage values of the tolerable daily intake (TDI) of this metal through consumption of drinking water in three control study areas.

The estimated average CDI values of uranium by drinking water pathway through well water were found to vary from 0.0017 to $0.013 \mu \mathrm{g} \cdot \mathrm{kg}^{-1} \cdot \mathrm{day}^{-1}$ (adults) and from 0.0052 
Table 1. Parameters characterizing log-normal distributions of log uranium concentrations determined in private drilled wells located in the control study areas CSA-A, CSA-B and CSA-C

\begin{tabular}{|c|c|c|c|c|c|c|c|c|c|}
\hline 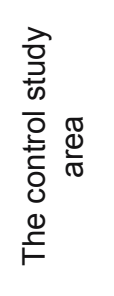 & 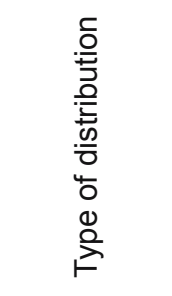 & 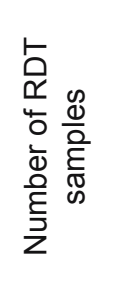 & 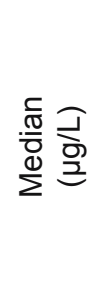 & 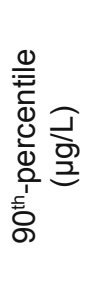 & 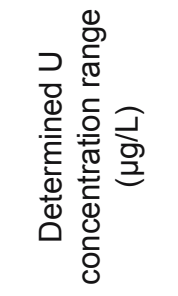 & 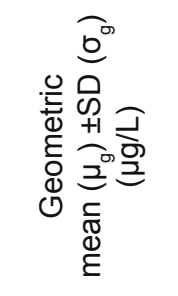 & 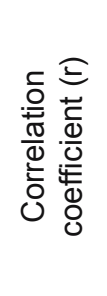 & 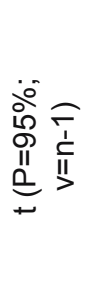 & 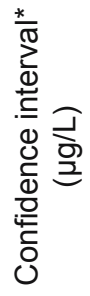 \\
\hline CSA-A & log-normal & $n=15$ & 0.061 & 0.67 & $0.005-1.03$ & $0.052 \pm 4.4$ & 0.981 & 2.1 & \pm 2.3 \\
\hline CSA-B & log-normal & $n=13$ & 0.44 & 1.68 & $0.027-10.6$ & $0.40 \pm 5.5$ & 0.982 & 2.2 & \pm 2.8 \\
\hline CSA-C & log-normal & $n=10$ & 0.18 & 17.3 & $0.006-27.1$ & $0.38 \pm 13$ & 0.971 & 2.3 & \pm 6.4 \\
\hline
\end{tabular}

* Confidence interval $=t \cdot\left(\sigma_{g} / \sqrt{ } n\right)$

Table 2. The estimated average and ranges of individual chronic daily intake values (AVG CDI and IND CDI range) and average and ranges of individual percentage values of tolerable daily intake (AVG \%TDI and IND \%TDI range) of uranium through consumption of drinking water in the control study areas

\begin{tabular}{|c|c|c|c|c|c|c|c|c|}
\hline \multirow[t]{2}{*}{$\begin{array}{l}\text { The control } \\
\text { study area }\end{array}$} & \multicolumn{2}{|c|}{$\begin{array}{c}\text { AVG CDI } \\
\left(90^{\text {th }} \text {-percentile CDI }\right) \\
\left(\mu \mathrm{g} \cdot \mathrm{kg}^{-1} \cdot \text { day }^{-1}\right)\end{array}$} & \multicolumn{2}{|c|}{$\begin{array}{c}\text { AVG \%TDI } \\
\left(90^{\text {th }} \text { percentile \%TDI) }\right. \\
(\%)\end{array}$} & \multicolumn{2}{|c|}{$\begin{array}{l}\text { IND CDI range } \\
\left(\mu \mathrm{g} \cdot \mathrm{kg}^{-1} \cdot \mathrm{day}^{-1}\right)\end{array}$} & \multicolumn{2}{|c|}{$\begin{array}{c}\text { IND \%TDI range } \\
(\%)\end{array}$} \\
\hline & adults & children & adults & children & adults & children & adults & children \\
\hline CSA-A & $\begin{array}{l}0.0017 \\
(0.022)\end{array}$ & $\begin{array}{l}0.0052 \\
(0.067)\end{array}$ & $\begin{array}{l}0.17 \\
(2.2)\end{array}$ & $\begin{array}{l}0.52 \\
(6.7)\end{array}$ & $0.0002-0.034$ & $0.0005-0.103$ & $0.02-3.4$ & $0.05-10.3$ \\
\hline CSA-B & $\begin{array}{c}0.013 \\
(0.056)\end{array}$ & $\begin{array}{l}0.040 \\
(0.17)\end{array}$ & $\begin{array}{c}1.3 \\
(5.6)\end{array}$ & $\begin{array}{l}4.0 \\
(17)\end{array}$ & $0.0009-0.35$ & $0.0027-1.06$ & $0.09-35$ & $0.27-106$ \\
\hline CSA-C & $\begin{array}{l}0.013 \\
(0.58)\end{array}$ & $\begin{array}{c}0.038 \\
(1.73)\end{array}$ & $\begin{array}{c}1.3 \\
(58)\end{array}$ & $\begin{array}{c}3.8 \\
(173)\end{array}$ & $0.0002-0.90$ & $0.0006-2.71$ & $0.02-90$ & $0.06-271$ \\
\hline
\end{tabular}

to $0.040 \mu \mathrm{g} \cdot \mathrm{kg}^{-1} \cdot \mathrm{day}^{-1}$ (children), while individual CDI values of $U$ were in the ranges of $0.0002-0.90 \mu \mathrm{g} \cdot \mathrm{kg}^{-1} \cdot \mathrm{day}^{-1}$ (adults) and $0.0005-2.71 \mu \mathrm{g} \cdot \mathrm{kg}^{-1} \cdot \mathrm{day}^{-1}$ (children). The CDI values were compared with the tolerable daily intake (TDI) value proposed by WHO in 2011 (World Health Organization 2011) $\left(1 \mu \mathrm{g} \cdot \mathrm{kg}^{-1} \cdot \mathrm{day}^{-1}\right)$. In the cases of adults and children, the average $\%$ TDI values were estimated at the levels of: $0.17 \%$ and $0.52 \%, 1.3 \%$ and $4.0 \%$, and $1.3 \%$ and $3.8 \%$ for CSA-A, CSA-B and CSA-C, respectively. On the other hand, after taking into account the estimated individual CDI values, the contribution of drinking water to TDI can reach even 90\% (adults) and 271\% (children), indicating essential human health risk in the cases of children consuming well water from two areas - CSA-B and CSA-C. Generally, 5.3\% of the randomly sampled wells have uranium concentrations exceeding $10 \mu \mathrm{g} / \mathrm{L}$.

\section{Conclusions}

Human exposure to uranium through drinking water consumption is usually minor but in areas where its concentrations are high, drinking water can constitute an important and dominant pathway of non-occupational exposure to this metal. Natural uranium contamination in drinking water is most likely to occur by ingestion of groundwater from non-monitored private drilled wells located in rural areas influenced by mining activity. Such situation can be observed in the cases of private drilled wells located in the two control study areas investigated in the Lower Silesian region in Poland (CSA-B and CSA-C), where the uranium concentrations reached values higher than $10 \mu \mathrm{g} / \mathrm{L}$ (the highest $\mathrm{U}$ conc. $=27.1 \mu \mathrm{g} / \mathrm{L}$ ). The high uranium concentration $(10.6 \mu \mathrm{g} / \mathrm{L})$ was found in groundwater collected from an approximately fifty-meter-deep drilled well (CSA-B). Evidently, this well has been drilled through a rich natural uranium deposit. Nevertheless, it should be noted that the highest concentrations of this metal were found in the cases of private groundwater wells situated within the shortest distance from the former uranium mines and/or mine slag heaps.

In the aquatic environment dissolved uranium can migrate relatively long distances from its source. This was confirmed in the case of CSA-C where uranium is transported with the Kleśnica River, which flows into the Morawka River. The concentration of this metal in the Morawka River was determined at the level of $0.099 \mu \mathrm{g} / \mathrm{L}$. This value was considerably lower than that observed in the water sample collected from the Morawka River $(1.19 \mu \mathrm{g} / \mathrm{L})$, after the point of linking these two rivers.

The study has shown that well water can, depending on the local geology, have in some cases uranium contents which could be sufficient to endanger children health. All 
the investigated private groundwater wells had uranium concentration below the WHO limit $(30 \mu \mathrm{g} / \mathrm{L}$ (World Health Organization 2011)), however, in two cases the observed concentrations were higher than $10 \mu \mathrm{g} / \mathrm{L}$. As clear evidence of the chemical toxicity of uranium has been indicated for many years, it seems that the parametric value for this metal should be included in the new amended European Union Drinking Water Directive and in order to protect children health such value should be set at the level proposed in Germany $(10 \mu \mathrm{g} / \mathrm{L})$ (Bundesministerium für Gesundheit 2001). Additionally, all drilled wells from such areas should be controlled, since the uranium concentrations can significantly differ from site to site.

\section{Acknowledgements}

This study was supported by the National Science Centre (Krakow, Poland), Project No. N N404 258840 (2011-2014). Special thanks to Mr. Jakub Bratkowski for providing background of maps originated from ArcGIS software v. 9.2 (ESRI) available in Department of the Environmental Hygiene of National Institute of Public Health - NIH.

\section{References}

[1] Bundesministerium für Gesundheit. Verordnung über die Qualität von Wasser für den menschlichen Gebrauch (Trinkwasserverordnung - TrinkwV 2001). (http://www.gesetze-im-internet.de/trinkwv_2001/BJNR095910001. html\#BJNR095910001BJNG000201310 (2013.07.03)).

[2] Cardew, P.T. (2003). A method for assessing the effect of water quality changes on plumbosolvency using random daytime sampling, Water Research, 37, pp. 2821-2832.

[3] European Community (1998). Council Directive 98/83/EC of 3rd November 1998 on the quality of water intended for human consumption, Official Journal of the European Communities, L330, pp. 32-54.

[4] European Food Safety Authority (2009). Uranium in foodstuffs, in particular mineral water. Scientific Opinion of the Panel on Contaminants in the Food Chain, The EFSA Journal, 1018, pp. 1-59.

[5] Garboś, S. \& Święcicka, D. (2012a). QC/QA scheme applied for monitoring of metals concentrations in water intended for human consumption sampled from the area of Warsaw performed by ICP-MS and ICP-OES techniques. In P. Bhattacharya, I. Rosborg, A. Sandhi, C. Hayes, M.J. Benoliel (Eds.), Proceedings of the 4th International Conference of COST Action 637: Metals and related Substances in Drinking Water (METEAU) (pp. 20-32), Oct 13-15 2010, Kristianstad, Sweden. IWA Publishing, London 2012.

[6] Garboś, S. \& Święcicka, D. (2012b). Silver migration from silver-modified activated carbon applied as a water filtration medium in classic cartridges of jug filter systems, Food Additives and Contaminants Part A, 29(11), pp. 1810-1819.

[7] Harper, R.M. \& Kantar, C. (2008). Uranium. In S.E. Jorgensen \& B.D. Fath (Eds.), Ecotoxicology (pp. 3662-3665). Elsevier B.V., Oxford 2008.

[8] Hartsch, J., Waage, S., Grabas, K. \& Koszela, J. (2007). Final Report. Overcome of negative consequences of mining activity - handling with radioactive contaminants in the region of Jelenia Góra situated in south-western Poland. Project No. FKZ 38001140 (in Polish). BMU/UBA, Halsbrücke 2007.

[9] Hayes, C.R. \& Croft, T.N. (2012). An investigation into the representativeness of random daytime sampling for lead in drinking water, using computational modeling, Journal of Water Supply: Research and Technology - AQUA, 61(3), pp. 142-152.

[10] Katsoyiannis, I.A., Hug, S.J., Ammann, A., Zikoudi, A. \& Hatziliontos, C. (2007). Arsenic specification and uranium concentrations in drinking water supply wells in Northern Greece: Correlations with redox indicative parameters and implications for groundwater treatment, Science of The Total Environment, 383, pp. 128-140.

[11] Kurttio, P., Auvinen, A., Salonen, L., Saha, H., Pekkanen, J. \& Makelainen, I. et al. (2002). Renal effects of uranium in drinking water, Environmental Health Perspectives, 110, pp. 337-342.

[12] Kurttio, P., Komulainen, H., Leino, A., Salonen, L., Auvinen, A. \& Saha, H. (2005). Bone as a possible target of chemical toxicity of natural uranium in drinking water, Environmental Health Perspectives, 113, pp. 68-72.

[13] PN-EN ISO 5667-3:2005 Water quality - Sampling - Part 3: Guidance on the preservation and handling of water samples.

[14] Schnug, E., Steckel, H. \& Haneklaus, S. (2005). Contribution of uranium in drinking water to the daily uranium intake of humans - a case study from Northern Germany, Landbauforschung Völkenrode, 55, pp. 227-236.

[15] Sheppard, M.I. (1980). The environmental behavior of uranium and thorium. Technical Report AECL-6795. Whiteshell Nuclear Research Establishment and Atomic Energy of Canada Ltd., Pinawa (Manitoba) 1980.

[16] Slaats, P.G.G., Blokker, E.J.M. \& Versteegh, J.F.M. (2007). Sampling Metals at the tap: Analyses of Dutch data over the period 2004-2006. In Proceeding Book of 1st International Conference of the COST Action 637: Metals and related substances in drinking water (METAU) (pp. 61-69), Oct 24-26 2007, Antalya, Turkey. European Cooperation in the Field of Scientific and Technical Research, Antalya 2007.

[17] Smedley, P.L., Smith, B., Abesser, C. \& Lapworth, D. (2006). Commissioned report CR/06/050N. Uranium occurrence and behaviour in British groundwater. Groundwater systems \& water quality programme. British Geological Survey, Nottingham 2006. 
[18] Suponik, T. \& Lutyński, M. (2009). Possibility of using permeable reactive barrier in two selected dumping sites, Archives of Environmental Protection, 35 (3), pp. 109-122.

[19] United States Environmental Protection Agency (2009). National Primary Drinking Water Regulations. EPA 816-F-09-0004, May 2009, (http://water.epa.gov/drink/contaminants/index.cfm\#Inorganic(03.07.2013)).

[20] Witczak, S., Garboś, S., Kmiecik, E., Siepak, M., Święcicka, D. \& Wątor, K. (2011). Chapter 11.2. The proposition of methodology for zones with more than 5000 habitants being supplied with drinking water. In Postawa A. \& Witczak S. (Eds.), Metals and related substances in water intended for human consumption in Poland (pp. 202-218). AGH, Kraków 2011.

[21] World Health Organization (2011). Uranium. In Guidelines for drinking-water quality, 4th ed. (pp. 430-431), WHO, Geneva 2011.

[22] Wrenn, M.E., Durbin, P.W., Howard, B., Lipsztein, J., Rundo J. \& Still, E.T. (1985). Metabolism of ingested U and Ra, Health Physics, 48, pp. 601-633.

[23] Zamora, M.L., Tracy, B.L., Zielinski, J.M., Meyerhof, D.P. \& Moss, M.A. (1998). Chronic ingestion of uranium in drinking water: a study of kidney bioeffects in humans, Toxicological Sciences, 43, pp. 68-77.

[24] Zamora, M.L., Zielinski, J.M., Meyerhof, D. \& Tracy, B. (2002). Gastrointestinal absorption of uranium in humans, Health Physics, 83, pp. 35-45.

[25] Závodská, L., Kosorínová, E., Ščerbáková, L. \& Lesný, J. Environmental chemistry of uranium. HU ISSN 1418-7108: HEJ Manuscript no.: ENV-081221-A. (http://heja.szif.hu/ENV/ENV-081221-A/env081221a.pdf $(03.07 .2013))$.

\section{Ocena ryzyka zdrowotnego związanego z obecnością uranu w wodzie przeznaczonej do spożycia pobieranej $z$ wierconych studni zlokalizowanych na obszarach wiejskich Dolnego Śląska (Polska)}

Stężenia uranu w wodach gruntowych pobieranych z prywatnych studni wierconych nie były dotąd badane w Polsce. W związku z tym, brak jest jakichkolwiek danych pozwalających na określenie narażenia ludzi na uran, związanego z konsumpcją wody przeznaczonej do spożycia, w szczególności na obszarach wiejskich, na terenach których prowadzono działalność górniczą. Głównym celem niniejszej pracy była ocena ryzyka zdrowotnego związanego z konsumpcją wód studziennych zawierających uran, pobieranych z wytypowanych obszarów wiejskich Dolnego Śląska (Polska). Do pobierania próbek wód studziennych z trzech obszarów badań kontrolnych (CSA): Mniszków (CSA-A), Stara Kamienica/M. Kamienica/Kopaniec (CSA-B) i Kletno (CSA-C), została zastosowana metoda RDT (ang.: Random DayTime). Analizy próbek RDT przeprowadzono za pomocą zwalidowanej metody opartej na spektrometrii mas z jonizacją w plazmie indukcyjnie sprzężonej (ICP-MS). Zakresy stężeń uranu w wodach studziennych i wyznaczone średnie geometryczne stężenia U w przypadkach poszczególnych obszarów wynosiły: 0,005-1,03 $\mu \mathrm{g} / \mathrm{L}$ i $0,052 \mu \mathrm{g} / \mathrm{L}$ (CSA-A), 0,027-10,6 $\mu \mathrm{g} / \mathrm{L} \mathrm{i} 0,40 \mu \mathrm{g} / \mathrm{L}$ (CSA-B) oraz 0,006-27,1 $\mu \mathrm{g} / \mathrm{L} \mathrm{i} \mathrm{0,38} \mu \mathrm{g} / \mathrm{L}$ (CSA-C). Średnie i indywidualne chroniczne dzienne pobrania (CDI, ang. Chronic Daily Intake) uranu związane z konsumpcją wody przeznaczonej do spożycia (dorośli/dzieci) zawarte były odpowiednio w zakresach: 0,0017-0,013/0,0052-0,040 $\mu \mathrm{g} \cdot \mathrm{kg}^{-1} \cdot \mathrm{dzien}{ }^{-1}$ i $0,0002-0,90 / 0,0005-2,71 \mu \mathrm{g} \cdot \mathrm{kg}^{-1} \cdot \mathrm{dzien}^{-1}$. Wyznaczone średnie i zakresy indywidualnych procentowych udziałów wartości CDI w tolerowanym dziennym pobraniu (TDI $=1 \mu \mathrm{g} \cdot \mathrm{kg}^{-1} \cdot \mathrm{dzien}^{-1}$, ang. Tolerable Daily Intake) (dorośli/dzieci) wynosiły: 0,17\%/0,52\% i $0,02-3,4 \% / 0,05-10,3 \%$ (CSA-A), $1,3 \% / 4,0 \%$ i $0,09-35 \% / 0,27-106 \%$ (CSA-B) oraz 1,3\%/3,8\% i $0,02-90 \% / 0,06-271 \%$ (CSA-C). Wyznaczone średnie wartości CDI uranu są znacząco niższe od ustalonej wartości TDI, podczas gdy w przypadkach indywidualnych wartości CDI ich udział w TDI może osiągać nawet 90\% (dorośli) i 271\% (dzieci), implikując istotne zagrożenie zdrowia dzieci spożywających wodę z prywatnych studni wierconych na obszarach CSA-B i CSA-C $(5,3 \%$ całkowitej ilości pobranych próbek). 